\title{
Rapid degradation of zinc oxide nanoparticles by phosphate ions
}

\author{
Rudolf Herrmann $^{* 1}$, F. Javier García-García ${ }^{1,2}$ and Armin Reller ${ }^{1}$
}

\section{Full Research Paper}

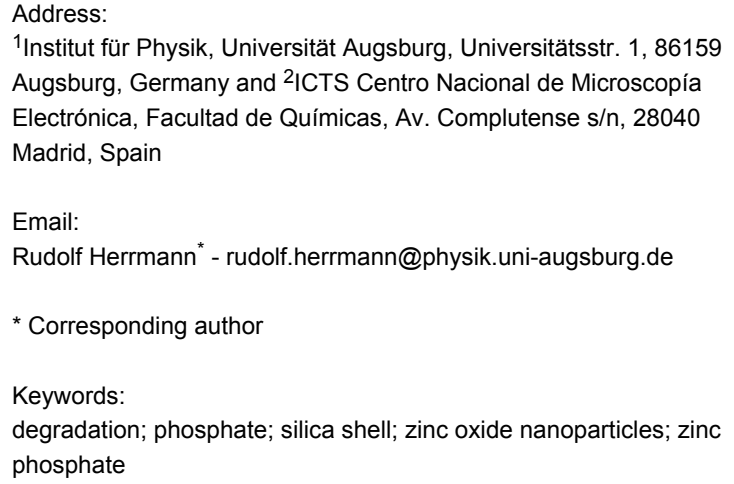

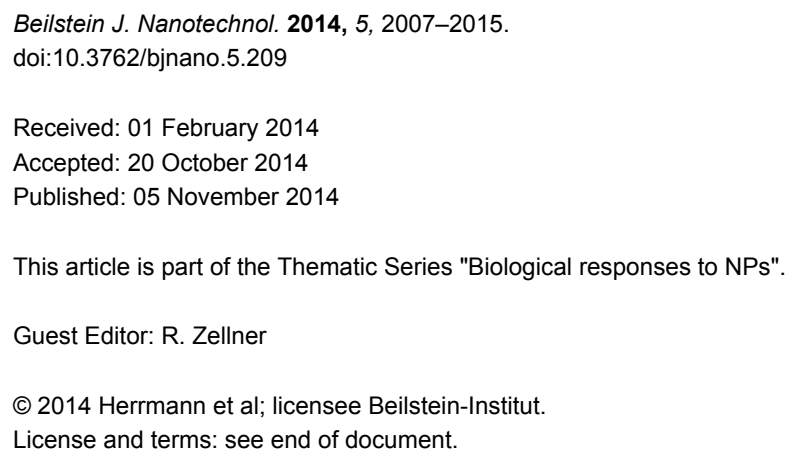

\begin{abstract}
Zinc oxide nanoparticles are highly sensitive towards phosphate ions even at $\mathrm{pH}$ 7. Buffer solutions and cell culture media containing phosphate ions are able to destroy $\mathrm{ZnO}$ nanoparticles within a time span from less than one hour to one day. The driving force of the reaction is the formation of zinc phosphate of very low solubility. The morphology of the zinc oxide particles has only a minor influence on the kinetics of this reaction. Surface properties related to different production methods and the presence and absence of labelling with a perylene fluorescent dye are more important. Particles prepared under acidic conditions are more resistant than those obtained in basic or neutral reaction medium. Surprisingly, the presence of a $\mathrm{SiO}_{2}$ coating does not impede the degradation of the $\mathrm{ZnO}$ core. In contrast to phosphate ions, $\beta$-glycerophosphate does not damage the $\mathrm{ZnO}$ nanoparticles. These findings should be taken into account when assessing the biological effects or the toxicology of zinc oxide nanoparticles.
\end{abstract}

\section{Introduction}

Crystalline nanoparticles of the semiconductor zinc oxide (ZnO-NP) show a broad fluorescence band in the visible range when excited in the UV region [1]. During first tests of ZnO-NP for their interaction with biological systems in the SPP 1313 priority programme (BioNanoResponses) we observed that this fluorescence is rapidly (within seconds) quenched in some cell culture media. Tracing the effect back to its roots revealed that the presence of phosphate ions in the media is responsible for the quenching. We now wish to present results which show that the interaction with phosphate ions is not limited to the surface of the nanoparticles but finally leads to their complete destruction.

It is well known that zinc oxide can react with phosphoric acid to form various zinc phosphates which have applications, e.g., as dental cement [2]. Zinc phosphate can also be used as 
corrosion inhibitor for metals as it forms a protecting layer on metal surfaces [3]. This usage is possible because of the low solubility of tertiary zinc phosphate (solubility product for $\mathrm{Zn}_{3}\left(\mathrm{PO}_{4}\right)_{2}$ : ca. $10^{-34}(\mathrm{~mol} / \mathrm{L})^{5}$ [4]. However, it is often necessary to ensure tight coatings by additives [5].

The reactivity of bulk zinc oxide with phosphate ions has formerly been studied mainly from a geological point of view (alkaline solution, high temperature) [6,7]. Particles between 200 and $400 \mathrm{~nm}$ react with orthophosphate and polyphosphate ions under neutral and alkaline conditions under partial dissolution resulting in the formation of zinc phosphates at the surface [8].

Since $\mathrm{ZnO}-\mathrm{NP}$ are used technically, e.g., as UV blockers in cosmetics, studies on interactions with biological systems are necessary. Cell culture media contain varying amounts of phosphate ions, from low (less than $100 \mathrm{mg} / \mathrm{L}$, as in human blood) to high (more than $1000 \mathrm{mg} / \mathrm{L}$ for $\mathrm{CO}_{2}$-independent media). One can therefore expect that the choice of the cell culture medium is of crucial importance for biological studies of ZnO-NP. In this context, the effect of water itself must be distinguished from that of the phosphate ions. Aggregation of $\mathrm{ZnO}$ nanoparticles in water was attributed to partial dissolution [9]. Morphological changes of $\mathrm{ZnO}$ nanocrystals under the influence of atmospheric water have been reported [10]. We therefore tested the influence of pure water on size and morphology the $\mathrm{ZnO}$ NP always in parallel with the reactions of phosphate buffers.

The toxicity of zinc oxide was found not to be related to particle size since toxic effects in water dispersions are due to $\mathrm{Zn}^{2+}$ ions whose concentration is almost equal in any sample within three days at pH 7.6 [11]. However, another investigation showed a higher toxicity for smaller particles [12]. In addition, the toxicity to marine organism was found to be shape-dependent [13]. Toxicity seems to parallel $\mathrm{Zn}^{2+}$ concentration which in turn is determined by the thermodynamics and kinetics of the ZnO-NP dissolution [14]. Newer results have shown that ZnO-NP can survive the cell culture media used for the studies under certain conditions, and are dissolved inside the cells after uptake. Most of their toxicity is then due to the increased $\mathrm{Zn}^{2+}$ concentration in the cells and formation of zinc complexes by molecular ligands [15]. Concerning dissolution kinetics of $\mathrm{ZnO}$ in aqueous media, no clear picture can be derived from the available data. While some find a size dependence $[16,17]$, others do not $[11,18,19]$. The initial concentration of the $\mathrm{ZnO}-\mathrm{NP}$ is reported to be important by some [20] but to be negligible by others [13] For $\mathrm{ZnO}$ there is a high probability that different phosphate contents in the media used for the investigations significantly influence the results since a lower phosphate concentration increases the lifetime of the $\mathrm{ZnO}$ particles but at the same time allows for higher $\mathrm{Zn}^{2+}$ concentrations. That the dissolution of $\mathrm{ZnO}-\mathrm{NP}$ depends on the medium is generally agreed $[19,21,22]$. The complexity of dissolution processes on several NP types in media, buffers and water has been stressed recently [23]. Special attention to the effects of phosphate around neutral $\mathrm{pH}$ has been payed only very recently [24].

The photocatalytic activity of $\mathrm{ZnO}$ nanoparticles can be significantly reduced by coating with $\mathrm{SiO}_{2}$ [25]. This is important when $\mathrm{ZnO}-\mathrm{NP}$ are applied as UV blockers. We therefore also included $\mathrm{ZnO}-\mathrm{NP}$ coated with silica in our tests.

\section{Results and Discussion}

We tested $\mathrm{ZnO}-\mathrm{NP}$ both in their native form and labelled at the surface with $N$-(2,5-bis(dimethylethyl)phenyl)- $N^{\prime}$-(3(triethoxysilyl)propyl)perylene-3,4,9,10-tetracarboxylic acid diimide (MDPI). This fluorescent dye is a convenient label for particles used in biomedical applications [26]. Similar perylenederived dyes were applied as sensitizers for zinc oxide solar cells [27]. ZnO samples 1 were prepared by a wet method under acidic conditions [28]. In the absence of the fluorescence marker we obtained almost spherical particles of 5-10 nm diameter clustering into small heaps (Figure 1, left). The presence of the fluorescence marker changes the morphology considerably and leads to rods and (approximate) spheres (Figure 2, left). DLS measurements show that the average size of the agglomerates is the same for both samples $(400 \mathrm{~nm})$ in water. Samples 2 were obtained by a wet method under basic conditions [29] leading to particles of spherical and hexagonal shape with diameters in the range of 5-25 $\mathrm{nm}$ (Figure 1, right). The presence or absence of the fluorescent dye did not have a significant effect on the morphology. The tendency to form agglomerates in water is higher for the labelled sample (DLS size 144 and $309 \mathrm{~nm}$, respectively). Sample 3 was commercial $\mathrm{ZnO}$ prepared by gas phase oxidation of zinc at high temperature, the so-called French process. It is a highly irregular mixture of particles with very different morphologies and sizes [30]. DLS measurements suggest similar agglomeration for labelled and unlabelled particles in water although DLS is not that reliable for such irregular particles since it was developed for spheres. All nanoparticles studied are composed of crystalline $\mathrm{ZnO}$ (zincite) phase, as confirmed by XRD.

Two buffers of the Sørensen type at pH 7.0 were applied. The concentration of phosphate was kept to $100 \mathrm{mg} / \mathrm{L}$, resembling the value in human blood (buffer A), or to $2000 \mathrm{mg} / \mathrm{L}$, similar to the value found in typical $\mathrm{CO}_{2}$-independent cell culture media (buffer B). For comparison, a solution of disodium $\beta$-glycerophosphate $(2000 \mathrm{mg} / \mathrm{L})$ was also used. After the reaction time $(1 \mathrm{~h}$ or $24 \mathrm{~h})$ all solid material was collected by centrifugation and subsequently washed three times with water 

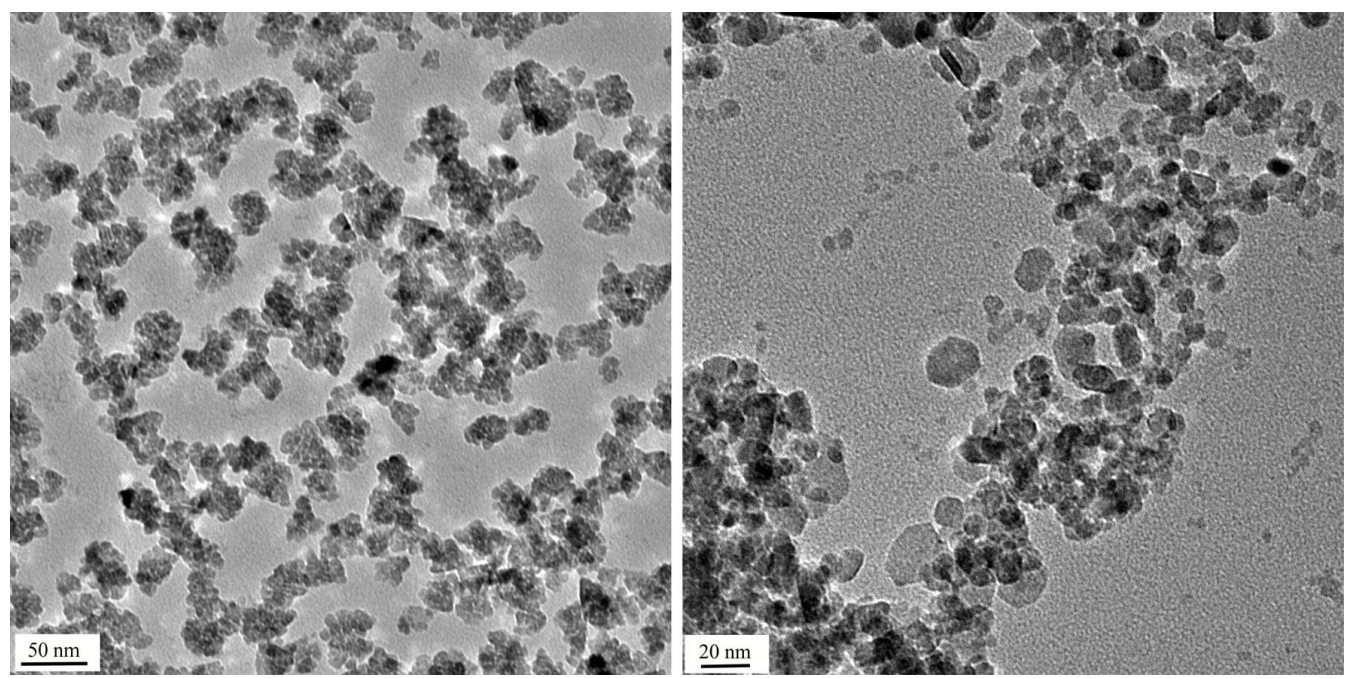

Figure 1: Left: ZnO-NP prepared by the acidic procedure (sample 1, without labelling; scale bar: $50 \mathrm{~nm}$ ). Right: ZnO NP prepared under alkaline conditions (sample 2, without labelling; scale bar: $20 \mathrm{~nm}$ ).
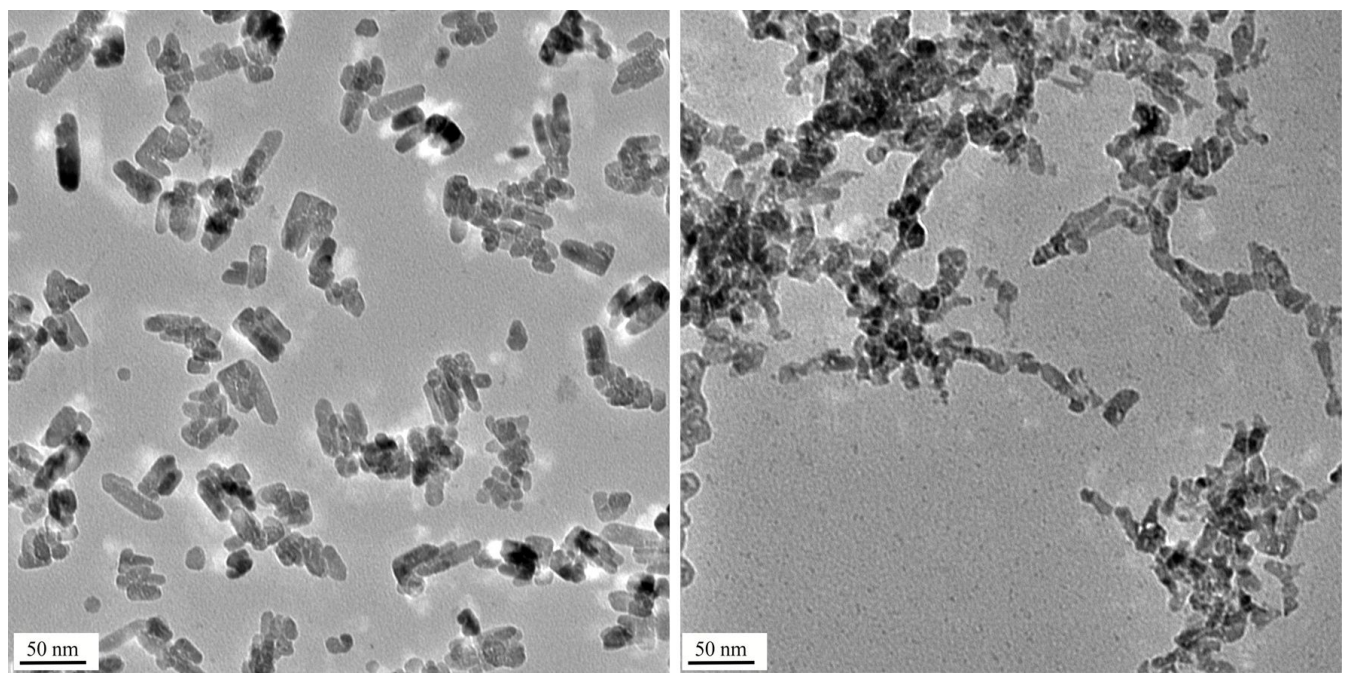

Figure 2: TEM pictures of ZnO-NP 1 (labeled with a perylene dye) as prepared (left) and after one hour of reaction with buffer A (right). The scale bars are $50 \mathrm{~nm}$.

to remove any soluble phosphate. The solid was then redispersed in ethanol and deposited on the copper grid for the subsequent TEM investigation. An aliquot was dissolved in acid and analyzed for the phophorus/zinc molar ratio by ICP-OES. The results are shown in Table 1. For pure $\mathrm{ZnO}$ the ratio is zero, and for pure tertiary zinc phosphate $2: 3$ is expected. A higher value indicates the presence of secondary zinc phosphate $\mathrm{ZnHPO}_{4}$ which generally precipitates faster than tertiary zinc phosphate despite its higher solubility [31]. Any intermediate value lower than 0.67 reflects a partial degradation of the $\mathrm{ZnO}$ NP. The error in the determination of the ratio is in the range of
$10 \%$. For phosphorus concentrations lower than $1 \mathrm{mg} / \mathrm{L}$ (very low conversion) the ICP-OES results are considered not reliable and therefore indicated as not determinable (n.d., i.e., close to zero) in the table.

The results clearly indicate that the degradation of the $\mathrm{ZnO}-\mathrm{NP}$ is almost complete for all of the samples after $24 \mathrm{~h}$. Some differences can, however, be observed after one hour of action of the buffer solutions. Thus, the particles in sample $\mathbf{1}$ (prepared under acidic conditions) are considerably more stable and only partially destroyed while there is almost no difference between 


\begin{tabular}{|c|c|c|c|c|}
\hline sample & $\begin{array}{l}\text { fluorescence } \\
\text { label }\end{array}$ & buffer & $\begin{array}{l}P / Z n \\
(1 \mathrm{~h})\end{array}$ & $\begin{array}{l}\mathrm{P} / \mathrm{Zn} \\
(24 \mathrm{~h})\end{array}$ \\
\hline 1 & - & A & n.d. & 0.59 \\
\hline 1 & + & A & n.d. & 0.72 \\
\hline 1 & - & B & 0.37 & 0.76 \\
\hline 1 & + & B & 0.23 & 0.66 \\
\hline 2 & - & A & 0.56 & 0.52 \\
\hline 2 & + & A & 0.61 & 0.60 \\
\hline 2 & - & B & 0.76 & 0.72 \\
\hline 2 & + & B & 0.62 & 0.72 \\
\hline 3 & - & A & 0.64 & 0.79 \\
\hline 3 & + & A & 0.63 & 0.66 \\
\hline 3 & - & B & n.d. & 0.71 \\
\hline 3 & + & B & 0.71 & 0.74 \\
\hline
\end{tabular}

one hour and one day for the particles in the other samples. As expected, buffer A (100 mg phosphate ions/L) shows a somewhat lower reactivity than buffer B $(2000 \mathrm{mg} / \mathrm{L})$. This allows one, in the case of the sample 1 , to observe the initial stage of the attack of the phosphate ions by TEM. Figure 2 shows the difference between the initial state (left) and after one hour of action of buffer A (right). The initially well-defined crystals (mainly rods and spheres) lose their shape and show a lower crystallinity at higher resolution of the TEM. They start to agglomerate strongly, a fact which we attribute mainly to the presence of amorphous zinc phosphate which acts as a glue for the remaining crystalline $\mathrm{ZnO}$ particles. Increasing agglomera- tion accompanying the partial dissolution of $\mathrm{ZnO}-\mathrm{NP}$ in phosphate-free buffers has been reported [32]. After $24 \mathrm{~h}$, all samples are of the same appearance. Only amorphous zinc phosphate forming approximately spherical particles with a high degree of agglomeration is observed, and the original shape of the $\mathrm{ZnO}-\mathrm{NP}$ is not reflected in that of the final products. XRD measurements after a $3 \mathrm{~h}$ treatment of the nanoparticles with buffer B confirm that the zinc phosphate formed is indeed amorphous, the only crystalline material in the samples being residual $\mathrm{ZnO}$. Note that sample 2 has already reached its final state after one hour (Figure 3, left). The precipitation of mainly amorphous zinc phosphate from solutions of zinc chloride and sodium phosphate in various cell culture media parallels this observation [33]. During the course of the reaction of buffer B with the nanoparticles for one hour, the $\zeta$-potential of all particle dispersions has a tendency to shift to more negative values, and the hydrodynamic diameter decreases (Table 2). Due to the highly irregular shape of the zinc phosphate particles and their varying agglomeration, no further conclusions can be drawn from these measurements.

Sample 3 is an exception to the general rule that lower phosphate concentration leads to slower destruction. When used without fluorescence label there is not much reaction with buffer B (2000 mg/L phosphate) but complete degradation with buffer A (100 mg/L) after one hour. However, after one day destruction is also complete with buffer B. This behaviour can be explained in terms of the formation of a relatively compact layer of sparingly soluble zinc phosphate at the surface, as in technical corrosion protection, which is induced by the high phosphate concentration. But the protection layer is not
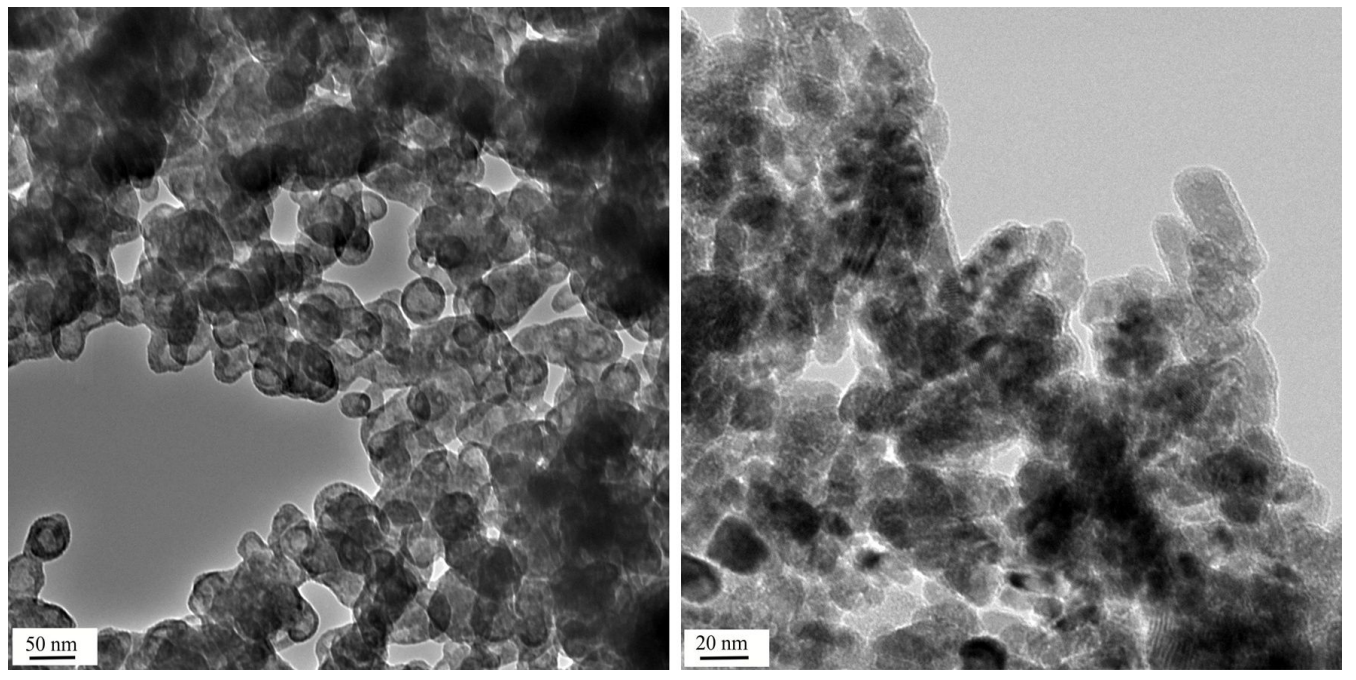

Figure 3: Left: TEM picture of degraded ZnO-NP 2 (labelled) after 1 hour of reaction with buffer B. The scale bar is $50 \mathrm{~nm}$. Right: Silica-coated ZnONP (sample 5). Shell thickness: $4-5 \mathrm{~nm}$. The scale bar is $20 \mathrm{~nm}$. 


\begin{tabular}{|c|c|c|c|c|c|}
\hline sample & $\begin{array}{l}\text { fluorescence } \\
\text { label }\end{array}$ & $\begin{array}{l}\zeta(\mathrm{mV}) \\
0 \mathrm{~h}\end{array}$ & $\begin{array}{l}\zeta(\mathrm{mV}) \\
1 \mathrm{~h}\end{array}$ & $\begin{array}{l}r(\mathrm{~nm}) \\
0 \mathrm{~h}\end{array}$ & $\begin{array}{l}r(\mathrm{~nm}) \\
1 \mathrm{~h}\end{array}$ \\
\hline 1 & - & -39.1 & -44.7 & 344 & 236 \\
\hline 1 & + & -46.1 & -50.2 & 427 & 408 \\
\hline 2 & - & -62.4 & -67.9 & 262 & 238 \\
\hline 2 & + & -66.1 & -77.0 & 243 & 161 \\
\hline 3 & + & -53.3 & -74.3 & 455 & 368 \\
\hline 4 & + & -58.3 & -56.7 & 478 & 382 \\
\hline 5 & + & -44.2 & -49.0 & 990 & 470 \\
\hline
\end{tabular}

completely compact so that after one day degradation is also complete. TEM pictures (Figure 4) show that the general appearance is still that of the starting material after one hour but signs of beginning destruction such as loss of the smooth surface and formation of agglomerates of amorphous zinc phosphate can already be seen. The zinc phosphate layer itself is not thick enough to be detected directly by TEM. Surface modification by labelling with the perylene fluorescence dye prevents the formation of a comparatively tight layer of zinc phosphate which leads to an almost complete degradation after one hour although few crystalline $\mathrm{ZnO}$ particles inside the amorphous agglomerate can still be observed by TEM at this point. This is no longer the case after one day.

During the etching of $\mathrm{ZnO}$ nanostructures with phosphatecontaining solutions [34] it was found that structures obtained by thermal evaporation (such as sample 3 ) generally dissolved slower than those from hydrothermal processes. This observa- tion is only partially applicable to the nanoparticles studied. Within one day all $\mathrm{ZnO}-\mathrm{NP}$ were completely destroyed by the phosphate buffers.

Photocatalytic activity of $\mathrm{ZnO}-\mathrm{NP}$, e.g., in oxidation reactions, is an unwanted feature when they are to be applied as UV blockers. Among the suggested coatings, which should block this activity, silica is mostly used in commercial preparations [25]. In principle, coatings should also prevent degradation by phosphate provided that the coating is sufficiently tight. We therefore extended our tests to two samples of coated $\mathrm{ZnO}-\mathrm{NP}$, one being a commercial sample (Maxlight ZS-64) used as obtained and labelled with the fluorescence dye (samples 4), while the other sample was prepared by coating of labelled ZnO-NP of sample $\mathbf{1}$ (prepared under acidic conditions) with a modified Stöber procedure [35] (sample 5).

It turned out, however, that the coating could not prevent degradation by phosphate. After $24 \mathrm{~h}$ the degradation was complete in all cases. The reaction rates were similar, regardless if the particles were used as received or labelled (samples $\mathbf{4}$, Figure 5, left), or if they were produced by a different process (sample 5). The zinc phosphate formed during the degradation process did not appear as amorphous material as in the tests with non-coated $\mathrm{ZnO}-\mathrm{NP}$ but as large crystals. The silica remained as heaps of empty shells clearly separated from the crystals (Figure 5, right). The separation of the two components was confirmed by EDX analysis of the two regions: the left regions (large crystals) shows zinc and phosphorus but no silicon while the right region (empty shells) shows silicon but no zinc or phosphorus. The degradation of the zinc oxide core
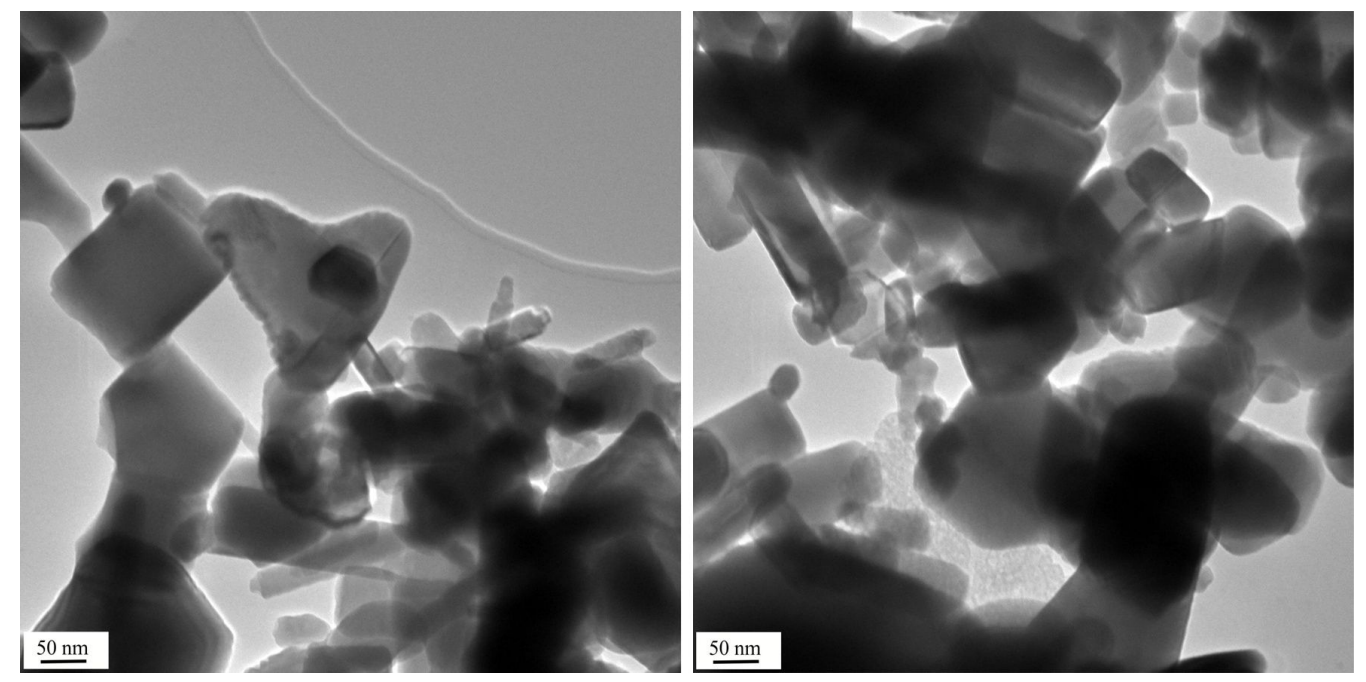

Figure 4: Commercial $\mathrm{ZnO}$ sample 3 after treatment with buffer $\mathrm{B}(2000 \mathrm{mg} / \mathrm{L})$ for one hour. The general appearance is still that of the starting material, but signs of beginning degradation can be seen at the margin of the central triangular particle (left), and amorphous zinc phosphate starts to appear in the lower part of the right picture. The scale bars are $50 \mathrm{~nm}$. 

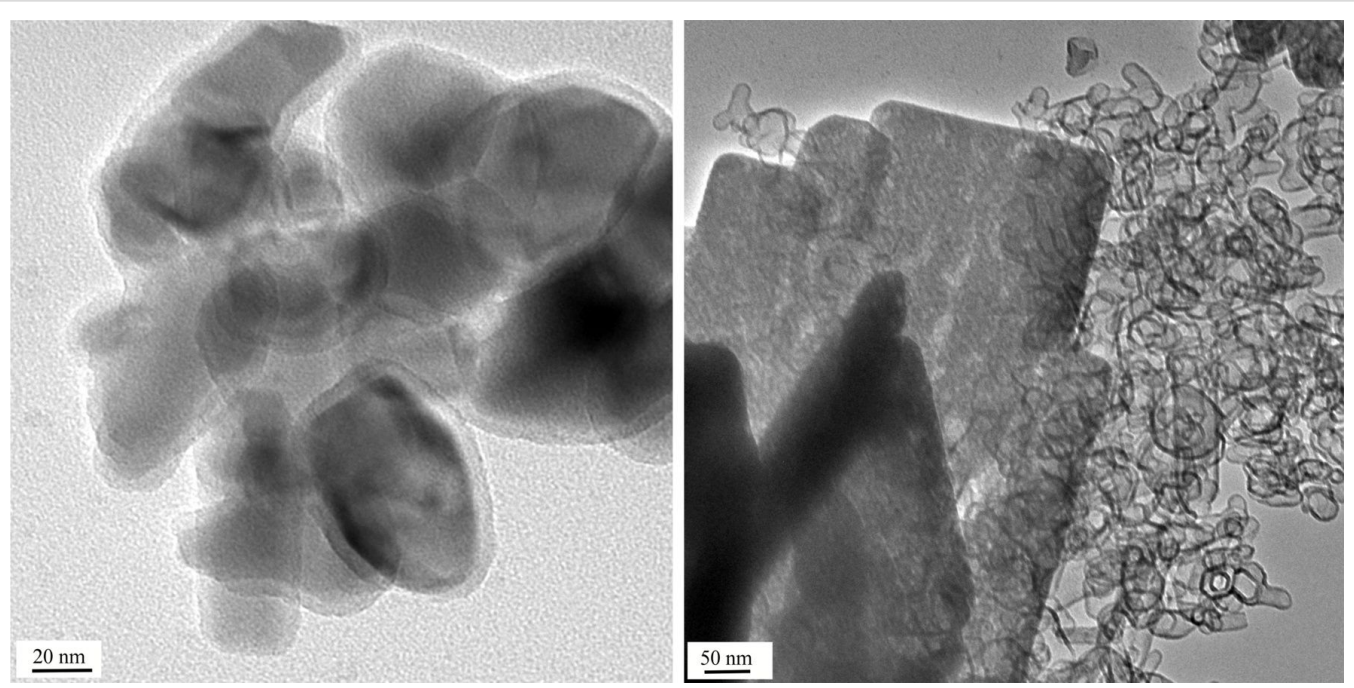

Figure 5: $\mathrm{SiO}_{2}$-coated labelled ZnO-NP (sample 4; shell thickness 3-6 nm) before (left; scale bar $20 \mathrm{~nm}$ ) and after (right; scale bar $50 \mathrm{~nm}$ ) $24 \mathrm{~h}$ degradation reaction with buffer $B$.

of the coated particles is therefore complete. The silica shell (thickness 3-6 nm) is obviously not sufficiently compact to prevent the access of water to the $\mathrm{ZnO}$ core.

Silica NP and shells formed by the Stöber process have a certain intrinsic porosity, which allows water and oxygen to pass at a limited rate (the diffusion coefficient of water being ten times lower than for unhindered diffusion [36]). Only silica layers with a thickness of about $100 \mathrm{~nm}$ or more were expected to be completely impenetrable for water and oxygen and would reliably block any chemical or photochemical reaction with the core material [37]. Although the resulting particles would be too big for applications as, e.g., UV blockers, it would be interesting to check the threshold shell thickness at which the degradation of the core by phosphate is no longer detectable; this is, however, beyond the scope of the current investigation.

XRD measurements of the partially transformed $\mathrm{ZnO}-\mathrm{NP}$ after $3 \mathrm{~h}$ revealed, in addition to $\mathrm{ZnO}$, the presence of two more crystalline phases, namely triclinic $\mathrm{Zn}_{3}\left(\mathrm{PO}_{4}\right)_{2} \cdot 4 \mathrm{H}_{2} \mathrm{O}$ (parahopeite), and $\mathrm{Zn}_{3}\left(\mathrm{PO}_{4}\right)_{2} \cdot 2 \mathrm{H}_{2} \mathrm{O}$. No hopeite (orthorhombic $\left.\mathrm{Zn}_{3}\left(\mathrm{PO}_{4}\right)_{2} \cdot 4 \mathrm{H}_{2} \mathrm{O}\right)$ was detected. In addition to amorphous zinc phosphate, hopeite and parahopeite were identified as reaction products from non-coated $\mathrm{ZnO}-\mathrm{NP}$ and phosphate in sodium nitrate solution [24] (but no dihydrate), and hopeite and dihydrate during the precipitation of zinc phosphate in cell culture media from $\mathrm{ZnCl}_{2}$ and phosphate solutions [33] (but no parahopeite).

Since our control experiments with water instead of phosphate buffer did not show any obvious change in size or morphology of the $\mathrm{ZnO}-\mathrm{NP}$ (both coated and uncoated), it is not the equilibrium $\mathrm{ZnO}+\mathrm{H}_{2} \mathrm{O} \leftrightarrow \mathrm{Zn}^{2+}{ }_{\text {aq }}+2 \mathrm{OH}^{-}$alone that is responsible for the dissolution of the NP. Only after diffusion of the $\mathrm{Zn}^{2+}{ }_{\text {aq }}$ ions through the pores to the exterior with high phosphate concentration, precipitation of zinc phosphate starts. This process is slower for coated particles than for uncoated particles for which a direct contact of phosphate ions with the $\mathrm{ZnO}$ surface is possible. This may account for the almost exclusive formation of crystalline zinc phosphate. The difference to the observed phases by others remains, however, unexplained.

\section{Conclusion}

Most nanoparticles are dynamical systems in aqueous solutions since equilibria between the solid state and the solution exist. This is in particular important for oxidic particles such as $\mathrm{SiO}_{2}$. Among the technically applied nanoparticles, zinc oxide is probably the most sensitive material in this respect. While the solubility in pure water is limited, one must carefully adapt the environment to its comparatively high reactivity. We could show that phosphate ions are able to degrade $\mathrm{ZnO}-\mathrm{NP}$ regardless if coated by silica or not.

The results are of importance for any investigation of the interaction of $\mathrm{ZnO}-\mathrm{NP}$ with biological systems and for toxicology studies when buffer solutions or cell culture media are applied $[38,39]$. It is essential to know the content of phosphate of these media before bringing them in contact with the $\mathrm{ZnO}-\mathrm{NP}$. For the rapid degradation of most of the particles a phosphate concentration of $100 \mathrm{mg} / \mathrm{L}$ (as in human blood) was sufficient. If no precautions are taken it is possible that the behaviour of zinc phosphate with respect to biological systems is determined instead that of $\mathrm{ZnO}$ nanoparticles. Some skepticism is also 
adequate for the interaction of particles having a zinc oxide shell with cells [40].

As a potential remedy for this situation, we suggest the use of $\beta$-glycerophosphate instead of phosphate in media and buffers. We found that ZnO-NP do not show any sign of attack by disodium $\beta$-glycerophosphate in a concentration of $2000 \mathrm{mg} / \mathrm{L}$ after one day. The reason is probably the much higher solubility of zinc glycerophosphate in water, compared with zinc phosphate, which does not lead to precipitation and equilibrium shifts. In the light of these results it seems essential to ensure a tight coating by a chemically resistant material before applying ZnO-NP for, e.g., medical or cosmetic purposes. Silica coating can suppress photocatalytic activity but cannot prevent destruction of the $\mathrm{ZnO}$ core. It remains to be determined if, e.g., a polyorganosiloxane coating performs better in this respect.

The presence of phosphate in the solution limits the concentration of $\mathrm{Zn}^{2+}{ }_{\text {aq }}$ since zinc phosphate precipitates rapidly. One could therefore consider its formation as a kind of detoxification. Small zinc phosphate particles might be transported to the liver for controlled recycling of the zinc ions [33].

\section{Experimental}

$N$-(2,5-Bis(dimethylethyl)phenyl)- $N$ '-(3-(triethoxysilyl)propyl)perylene-3,4,9,10-tetracarboxylic acid diimide (MDPI) was prepared as described [26]. The successful fluorescence labelling of $\mathrm{ZnO}-\mathrm{NP}$ was checked by irradiating the dispersions at $254 \mathrm{~nm}$. Dry solvents (stored over molecular sieves $4 \AA$ ) were used in all cases. Solvents and reagents were purchased from Merck unless otherwise noted. TEM pictures were taken with a JEM $2100 \mathrm{~F}$ instrument (Jeol, Tokyo, Japan) on a carbon-coated copper grid (Plano, Formvar/coal-film on a 200 mesh net). The size of agglomerates was determinated by DLS measurements, together with the $\zeta$-potential, with a Nano ZS instrument (Malvern Instruments), using dispersions of ca. $100 \mu \mathrm{g}$ per $\mathrm{mL}$. Powder XRD was performed with a Seifert 3003 TT instrument.

\section{Preparation of $\mathrm{ZnO}-\mathrm{NP}$ under acidic condi- tions [28] (sample 1)}

To a solution of $660 \mathrm{mg}(3.0 \mathrm{mmol})$ zinc acetate dihydrate in $15 \mathrm{~mL}$ of 1-pentanol and $7.5 \mathrm{~mL}$ of $o$-xylene, $56 \mathrm{mg}$ of toluenesulfonic acid monohydrate (Merck) were added and the mixture was heated to $140{ }^{\circ} \mathrm{C}$ under nitrogen for $4 \mathrm{~h}$. After cooling to room temperature the mixture was centrifuged at $2500 \mathrm{~g}$ for $40 \mathrm{~min}$ and the solid redispersed in $10 \mathrm{~mL}$ of ethanol and centrifuged again. This washing procedure was repeated two more times. From the mother liquors more product can be obtained by centrifugation at $13500 \mathrm{~g}$ and application of analogous washing procedures. The total yield was $120 \mathrm{mg}$ of $\mathrm{ZnO}$ nanoparticles $(50 \%)$. For the labelled nanoparticles, $3 \mu \mathrm{mol}$ $(2.3 \mathrm{mg})$ of MDPI were added before the addition of the toluenesulfonic acid. The same workup led to a total of $90 \mathrm{mg}$ (37\%). All particles were stored as dispersions in ethanol. $\zeta$-potential in water: $-48.3 \mathrm{mV}$; labelled: $-56.3 \mathrm{mV}$. DLS: $400 \mathrm{~nm}$, unlabelled; $401 \mathrm{~nm}$, labelled.

\section{Preparation of $\mathrm{ZnO}-\mathrm{NP}$ under basic condi- tions [29] (sample 2)}

To a solution of $\mathrm{KOH}(390 \mathrm{mg})$ in $50 \mathrm{~mL}$ of ethanol prepared at $60{ }^{\circ} \mathrm{C}$ under nitrogen were added $660 \mathrm{mg}$ (3.0 mmol) zinc acetate dihydrate and $8 \mathrm{~mL}$ of methanol. After stirring at $60{ }^{\circ} \mathrm{C}$ for $30 \mathrm{~min}$ and cooling to room temperature the mixture was centrifuged at $2500 \mathrm{~g}$ for $40 \mathrm{~min}$ and the solid was redispersed in $15 \mathrm{~mL}$ of ethanol and centrifuged again. The washing procedure was repeated two more times. The yield was $236 \mathrm{mg}$ (95\%). For the labelled nanoparticles, $3 \mu \mathrm{mol}(2.3 \mathrm{mg})$ of MDPI dissolved in $8 \mathrm{~mL}$ of methanol were added instead of the pure methanol. The yield was $204 \mathrm{mg}(83 \%)$. All particles were stored as dispersions in ethanol. $\zeta$-potential in water: $+47.3 \mathrm{mV}$; labelled: $+60.7 \mathrm{mV}$. DLS: $144 \mathrm{~nm}$, unlabelled; $309 \mathrm{~nm}$, labelled.

\section{Labelling of commercial $\mathrm{ZnO}$ nanopowder (sample 3)}

$\mathrm{ZnO}$ nanopowder was obtained from Sigma-Aldrich $(\leq 1 \mu \mathrm{m}$, purity $99.9 \%$ ). The powder (25 mg), $0.2 \mu \mathrm{g}$ of MDPI and $2.6 \mathrm{~mL}$ of ethanol were placed in a glass vial (volume $4 \mathrm{~mL}$ ) with a magnetic stirring bar and closed tightly by a screw cap with a teflon gasket. It was heated in an oil bath to $140{ }^{\circ} \mathrm{C}$ for $20 \mathrm{~h}$ under stirring. After cooling to room temperature the solid was separated by centrifugation $(9500 \mathrm{~g}, 20 \mathrm{~min})$, redispersed in $1 \mathrm{~mL}$ of ethanol and centrifuged again. The washing was repeated two more times. The yield was $22 \mathrm{mg}$ (88\%). The particles were stored as dispersions in ethanol. $\zeta$-potential in water: $-32.9 \mathrm{mV}$. DLS: $436 \mathrm{~nm}$.

\section{Labelling of commercial $\mathrm{SiO}_{2}$-coated $\mathrm{ZnO}-\mathrm{NP}$ (sample 4)}

A sample of Maxlight ZS-64 (Showa Denko, 77-82\% ZnO, $18-23 \% \mathrm{SiO}_{2}$ ) was labelled in analogy to the preceding procedure. The yield was $21 \mathrm{mg}(84 \%)$. $\zeta$-potential in water: $-32.1 \mathrm{mV}$. DLS: $454 \mathrm{~nm}$. Shell thickness (TEM) 3-6 nm.

\section{$\mathrm{SiO}_{2}$-coating of $\mathrm{ZnO}-\mathrm{NP}$ [35] (sample 5)}

To a stirred dispersion of $5 \mathrm{mg}$ of labelled $\mathrm{ZnO}-\mathrm{NP}$ (sample 1) in $0.2 \mathrm{~mL}$ of ethanol, $90 \mathrm{~mL}$ of water, $5 \mu \mathrm{L}$ of aqueous ammonia (25\%) and $5 \mu \mathrm{L}$ of tetraethoxsilane (TEOS, SigmaAldrich) was added. After stirring for $1 \mathrm{~h}$, the dispersion was centrifuged $(12000 \mathrm{~g}, 30 \mathrm{~min})$, redispersed in $0.5 \mathrm{~mL}$ of ethanol, centrifuged, then redispersed in $0.5 \mathrm{~mL}$ of water and 
centrifuged again. The resulting coated particles $(4.8 \mathrm{mg})$ were stored in ethanol $(1.0 \mathrm{~mL})$. $\zeta$-potential in water: $-31.3 \mathrm{mV}$. DLS: $620 \mathrm{~nm}$. Shell thickness (TEM): 4-5 nm.

\section{Reaction of $\mathrm{ZnO}-\mathrm{NP}$ with phosphate}

Buffer solutions of the Sørensen type were used at $\mathrm{pH} 7.0$ with $100 \mathrm{mg} / \mathrm{L}$ phosphate (buffer A) and $2000 \mathrm{mg} / \mathrm{L}$ (buffer B). In addition, a solution of $2000 \mathrm{mg} / \mathrm{L}$ of disodium $\beta$-glycerophosphate pentahydrate $(99.0 \%$, Calbiochem) was used for comparison.

Zinc oxide nanoparticles (samples 1, 2 and 3,1.25 mg each) were stirred with the buffer solutions $(30 \mathrm{~mL}$ for buffer $\mathrm{A}$, $1.5 \mathrm{~mL}$ for buffer $\mathrm{B}$ ) or the $\beta$-glycerophosphate solution $(4.9 \mathrm{~mL})$ for the appropriate time $(1 \mathrm{~h}$ or $24 \mathrm{~h})$. The dispersions were then centrifuged at $13500 \mathrm{~g}$ for $10 \mathrm{~min}$. The solid was redispersed in $1 \mathrm{~mL}$ of water and centrifuged again. This washing was repeated two more times. The final product was redispersed in $1.5 \mathrm{~mL}$ of ethanol, and $0.1 \mathrm{~mL}$ were used for TEM measurements. From the remaining solution the ethanol was evaporated and the residue was dissolved in $10 \mathrm{~mL}$ of $0.01 \mathrm{~N} \mathrm{HCl}$ and $10 \mathrm{~mL}$ of an aqueous solution of EDTA disodium salt $(10 \mathrm{mg})$ for ICP-OES analysis according to DIN EN 11885 (Bayerisches Institut für Angewandte Umweltforschung und -technik (bifa), Augsburg). The results are presented in Table 1 . In addition, the $\zeta$-potential and the hydrodynamic diameter were determined in buffer B immediately after dispersion and after one hour of reaction, using dispersions of ca. $100 \mu \mathrm{g}$ per $\mathrm{mL}$. The results are shown in Table 2 . XRD measurements were done on samples of ca. $20 \mathrm{mg}$ of nanoparticles treated with buffer $\mathrm{B}(6 \mathrm{~mL})$ for $3 \mathrm{~h}$, isolation of the solids by centrifugation, and air drying.

\section{Degradation of $\mathrm{SiO}_{2}$-coated $\mathrm{ZnO}-\mathrm{NP}$ by phosphate}

Silica-coated $\mathrm{ZnO}$ nanoparticles (samples $\mathbf{4}$ and 5, $2.4 \mathrm{mg}$ each) were stirred with buffer solutions A $(60 \mathrm{~mL})$ or B $(8 \mathrm{~mL})$ for 1 and $24 \mathrm{~h}$, respectively. After centrifugation $(12000 \mathrm{~g}, 15 \mathrm{~min})$ the samples were redispersed in water $(0.6 \mathrm{~mL})$ and centrifuged again. This washing procedure was repeated two more times. The products were stored in ethanol $(1 \mathrm{~mL})$ and analyzed by TEM. See Table 2 for DLS and $\zeta$-potentials. XRD measurements were carried out with samples of ca. $20 \mathrm{mg}$ of nanoparticles treated with buffer $\mathrm{B}(6 \mathrm{~mL})$ for $3 \mathrm{~h}$, isolation of the solids by centrifugation $(13000 \mathrm{~g})$ and drying in air.

\section{Acknowledgements}

The authors wish to thank the DFG (Deutsche Forschungsgemeinschaft) for supporting this work within the SPP 1313 (Biological Responses to Nanoscale Particles). We also wish to thank Showa Denko Europe for a sample of $\mathrm{SiO}_{2}$-coated $\mathrm{ZnO}$ nanoparticles (Maxlight ZS-64). For DLS measurements and $\zeta$-potential determinations, we wish to thank Adriano Torrano, LMU München, and Prof. Thomas Bein for providing access to the instrument. For XRD measurements, we wish to thank Andreas Kalytta-Mewes, Universität Augsburg, and Prof. Dirk Volkmer for providing access to the instrument.

\section{References}

1. Djurišić, A. B.; Leung, Y. H. Small 2006, 2, 944-961. doi:10.1002/smll.200600134

2. Servais, G. E.; Cartz, L. J. Dent. Res. 1971, 50, 613-620. doi:10.1177/00220345710500031601

3. Awad, S. A.; Kamel, K. M. J. Electroanal. Chem. 1970, 24, 217-225. doi:10.1016/S0022-0728(70)80023-7

4. Dupuis, V.; Laviole, O.; Potin-Gautier, M.; Castetbon, A.; Moya, F. Biomaterials 1992, 13, 467-470. doi:10.1016/0142-9612(92)90168-N

5. Sugama, T.; Takahasi, T. J. Mater. Sci. 1995, 30, 809-823. doi:10.1007/BF00356346

6. Ziemniak, S. E.; Opalka, E. P. Chem. Mater. 1994, 6, 461-467. doi:10.1021/cm00040a021

7. Ziemniak, S. E.; Jones, M. E.; Combs, K. E. S. J. Solution Chem. 1992, 21, 1153-1176. doi:10.1007/BF00651861

8. Michelmore, A.; Jenkins, P.; Ralston, J. Int. J. Miner. Process. 2003, 68, 1-16. doi:10.1016/S0301-7516(01)00085-0

9. Tso, C.-p.; Zhung, C.-m.; Shih, Y.-h.; Tseng, Y.-M.; Wu, S.-c.; Doong, R. a. Water Sci. Technol. 2010, 61, 127-133. doi:10.2166/wst.2010.787

10. Ali, M.; Winterer, M. Chem. Mater. 2010, 22, 85-91. doi:10.1021/cm902240c

11. Franklin, N. M.; Rogers, N. J.; Apte, S. C.; Batley, G. E.; Gadd, G. E.; Casey, P. S. Environ. Sci. Technol. 2007, 41, 8484-8490. doi:10.1021/es071445r

12. Jiang, W.; Mashayekhi, H.; Xing, B. Environ. Pollut. (Oxford, U. K.) 2009, 157, 1619-1625. doi:10.1016/j.envpol.2008.12.025

13. Peng, X.; Palma, S.; Fisher, N. S.; Wong, S. S. Aquat. Toxicol. 2011, 102, 186-196. doi:10.1016/j.aquatox.2011.01.014

14. Gilbert, B.; Fakra, S. C.; Xia, T.; Pokhrel, S.; Mädler, L.; Nel, A. E. ACS Nano 2012, 6, 4921-4930. doi:10.1021/nn300425a

15. Miao, A.-J.; Zhang, X.-Y.; Luo, Z.; Chen, C.-S.; Chin, W.-C.; Santschi, P. H.; Quigg, A. Environ. Toxicol. Chem. 2010, 29, 2814-2822. doi:10.1002/etc.340

16. Bian, S.-W.; Mudunkotuwa, I. A.; Rupasinghe, T.; Grassian, V. H. Langmuir 2011, 27, 6059-6068. doi:10.1021/la200570n

17. Mudunkotuwa, I. A.; Rupasinghe, T.; Wu, C.-M.; Grassian, V. H. Langmuir 2012, 28, 396-403. doi:10.1021/la203542x

18. Mortimer, M.; Kasemets, K.; Kahru, A. Toxicology 2010, 269, 182-189. doi:10.1016/j.tox.2009.07.007

19. Li, M.; Zhu, L.; Lin, D. Environ. Sci. Technol. 2011, 45, 1977-1983. doi:10.1021/es102624t

20. Baek, Y.-W.; An, Y.-J. Sci. Total Environ. 2011, 409, 1603-1608. doi:10.1016/j.scitotenv.2011.01.014

21. Xia, T.; Kovochich, M.; Liong, M.; Mädler, L.; Gilbert, B.; Shi, H.; Yeh, J. I.; Zink, J. I.; Nel, A. E. ACS Nano 2008, 2, 2121-2134. doi:10.1021/nn800511k

22. Reed, R. B.; Ladner, D. A.; Higgins, C. P.; Westerhoff, P.; Ranville, J. F. Environ. Toxicol. Chem. 2012, 31, 93-99. doi:10.1002/etc. 708 
23. Misra, S. K.; Dybowska, A.; Berhanu, D.; Luoma, S. N.; Valsami-Jones, E. Sci. Total Environ. 2012, 438, 225-232. doi:10.1016/j.scitotenv.2012.08.066

24. Lv, J.; Zhang, S.; Luo, L.; Han, W.; Zhang, J.; Yang, K.; Christie, P. Environ. Sci. Technol. 2012, 46, 7215-7221. doi:10.1021/es301027a

25. Wang, J.; Tsuzuki, T.; Sun, L.; Wang, X. J. Am. Ceram. Soc. 2009, 92, 2083-2088. doi:10.1111/j.1551-2916.2009.03142.x

26. Blechinger, J.; Herrmann, R.; Kiener, D.; García-García, F. J.; Scheu, C.; Reller, A.; Bräuchle, C. Small 2010, 6, 2427-2435. doi:10.1002/smll.201000762

27. Dentani, T.; Funabiki, K.; Jin, J. Y.; Yoshida, T.; Minoura, H.; Matsui, M. Dyes Pigm. 2007, 72, 303-307. doi:10.1016/j.dyepig.2005.09.004

28. Demir, M. M.; Muñoz-Esqui, R.; Lieberwirth, I.; Wegner, G. J. Mater. Chem. 2006, 16, 2940-2947. doi:10.1039/b601451h

29. Sun, D.; Wong, M.; Sun, L.; Li, Y.; Miyatake, N.; Sue, H.-J. J. Sol-Gel Sci. Technol. 2007, 43, 237-243. doi:10.1007/s10971-007-1569-z

30. Mahmud, S.; Abdullah, M. J.; Putrus, G. A.; Chong, J.; Mohamad, A. K. Synth. React. Inorg., Met.-Org., Nano-Met. Chem. 2006, 36, 155-159. doi:10.1080/15533170500524462

31. Rathje, W. Ber. Dtsch. Chem. Ges. 1941, 74, 546-552. doi:10.1002/cber.19410740410

32. David, C. A.; Galceran, J.; Rey-Castro, C.; Puy, J.; Companys, E.; Salvador, J.; Monné, J.; Wallace, R.; Vakourov, A. J. Phys. Chem. C 2012, 116, 11758-11767. doi:10.1021/jp301671b

33. Turney, T. W.; Duriska, M. B.; Jayaratne, V.; Elbaz, A.; O'Keefe, S. J.; Hastings, A. S.; Piva, T. J.; Wright, P. F. A.; Feltis, B. N. Chem. Res. Toxicol. 2012, 25, 2057-2066. doi:10.1021/tx300241q

34. Cheng, C.; Xin, R.; Leng, Y.; Yu, D.; Wang, N. Inorg. Chem. 2008, 47, 7868-7873. doi:10.1021/ic8005234

35. Han, K.; Zhao, Z.; Xiang, Z.; Wang, C.; Zhang, J.; Yang, B. Mater. Lett. 2007, 61, 363-368. doi:10.1016/j.matlet.2006.04.064

36. Lettinga, M. P.; van Zandvoort, M. A. M. J.; van Kats, C. M.; Philipse, A. P. Langmuir 2000, 16, 6156-6165. doi:10.1021/la9916023

37. Dembski, S.; Graf, C.; Krüger, T.; Gbureck, U.; Ewald, A.; Bock, A.; Rühl, E. Small 2008, 4, 1516-1526. doi:10.1002/smll.200700997

38. Lin, W.; Xu, Y.; Huang, C.-C.; Ma, Y. F.; Shannon, K. B.; Chen, D.-R.; Huang, Y.-W. J. Nanopart. Res. 2009, 11, 25-39. doi:10.1007/s11051-008-9419-7

39. Tsou, T.-C.; Yeh, S.-C.; Tsai, F.-Y.; Lin, H.-J.; Cheng, T.-J.; Chao, H.-R.; Tai, L.-A. J. Hazard. Mater. 2010, 183, 182-188. doi:10.1016/j.jhazmat.2010.07.010

40. Wang, H.; Wingett, D.; Engelhard, M. H.; Feris, K.; Reddy, K. M.; Turner, P.; Layne, J.; Hanley, C.; Bell, J.; Tenne, D.; Wang, C.; Punnoose, A. J. Mater. Sci.: Mater. Med. 2009, 20, 11-22. doi:10.1007/s10856-008-3541-z

\section{License and Terms}

This is an Open Access article under the terms of the Creative Commons Attribution License

(http://creativecommons.org/licenses/by/2.0), which permits unrestricted use, distribution, and reproduction in any medium, provided the original work is properly cited.

The license is subject to the Beilstein Journal of Nanotechnology terms and conditions: (http://www.beilstein-journals.org/bjnano)

The definitive version of this article is the electronic one which can be found at:

doi:10.3762/bjnano.5.209 